\title{
Analysis of the Methodology of Constructing a Production Function Using Quality Criteria
}

\author{
Skrynkovskyy R. M. ${ }^{1}$, Yuzevych V. M. ${ }^{2}$, Kataev A. V. ${ }^{3}$, Pawlowski G. ${ }^{4 *}$, Protsiuk T. B. ${ }^{5}$ \\ ${ }^{1}$ Lviv University of Business and Law, 99 Kulparkivska St., 79021 Lviv, Ukraine; \\ ${ }^{2}$ Karpenko Physico-Mechanical Institute of the NAS of Ukraine, 5 Naukova St., 79060 Lviv, Ukraine; \\ ${ }^{3}$ Kharkiv Institute of Trade and Economics of Kyiv National University of Trade and Economics, \\ 8 Otakara Yarosha St., 61045 Kharkiv, Ukraine; \\ ${ }^{4}$ Zaklad Handlowo-Uslugowy BHP”, 17 Kostrzynska St., 69-113 Gorzyca, Poland; \\ ${ }^{5}$ Academy of Financial Monitoring, 24 Biloruska St., 04050 Kyiv, Ukraine
}

Article info:

Paper received:

The final version of the paper received:

Paper accepted online:
July 20, 2018

December 16, 2018

December 20, 2018
*Corresponding Author's Address: gpawlowski@op.pl

Abstract. In the article to forecast the trends of development of the state's industry (for example, Ukraine), a method for evaluating the parameters included in the classical Cobb-Douglas formula is developed. On the basis of the computational experiment it was established that if the values of the production function $Y$ are close to the numerical values and the deviation between them does not exceed $3.7 \%$, then for approximation of $Y$ in the industry for small time periods, it makes no sense to complicate the set of its parameters and coefficients. For forecasting the values of $Y_{i}\left(Y_{i} \in Y\right)$ we have evaluated the parameters that are included in the classical Cobb-Douglas formula. To improve the methodology for estimating the coefficients included in the Cobb-Douglas type formula, new variants of the multiplicative and additive quality criteria and for the Ukrainian industry are proposed, based on the analytical data for 2010-2017, the evaluation of the relevant criteria was carried out.

Keywords: production function, Cobb-Douglas function, quality criteria, industry, industrial products.

\section{Introduction}

Over the past decades, a special feature of the practice of analyzing manufacturing processes has been the active use of special methods of statistics modelling. An important role in this context belongs to production functions.

At the present stage of research [1,2]:

1) the essence of the production function is that it enables to formulate concrete alternatives (variants) of the combination of factors of production to ensure a certain amount of production, that is, the possibility of one factor of production to replace others;

2) the production function is not only the prospect of one of the analytical methods for forecasting the development of the state's economy, but also an applied instrument used to assess and compare the effectiveness of national economies;

3) the macroeconomic production function has a wide range of applications, since its dynamic analysis allows to solve such key important tasks:

- study the dynamics of the efficiency of production factors (labor productivity, return on investments);
- identify factors of production growth;

- determine the contribution of each production factor to the overall increase in production.

For Ukraine in the conditions of European integration [3], where one of the pressing issues is today to identify the reserves of the growth of the national economy, the use of information about local rates of change in the production function can give impetus to the improvement of existing mechanisms for management and activation of internal factors of development.

\section{Literature Review}

In theoretical and applied analysis, the most widely used are the following 4 types of production functions:

1) linear [2, 4];

2) Cobb-Douglas function [2, 5-7];

3) function CES (with postmobile elastics) [2];

4) Leontief function [4].

Their advantages are small number of coefficients (parameters) [2], which greatly facilitates the statistical evaluation, as well as indicators of economic growth (effi- 
ciency, intensification), calculated on their basis, have a convenient analytical form.

Among the most famous functions is the classic production function of Cobb-Douglas, which has the form [5-7]:

$$
Y=A L^{\alpha} K^{\beta}
$$

where $A$ - technological coefficient (or coefficient characterizing production efficiency); $L-$ work resources; $K$ - volume of fixed investments; $\alpha, \beta$ - coefficients of elasticity for labor and investments, respectively.

Partial elasticity factor of the product on the funds:

$$
E_{K}=\frac{\partial Y}{\partial K} \frac{K}{Y}=A \beta L^{\alpha} K^{\beta-1} \frac{K}{A L^{\alpha} K^{\beta}}=\beta .
$$

Elasticity of the product by labor:

$$
E_{L}=\frac{\partial Y}{\partial L} \frac{L}{Y}=A \alpha L^{\alpha-1} K^{\beta} \frac{L}{A L^{\alpha} K^{\beta}}=\alpha .
$$

These coefficients of elasticity reflect the percentage of output growth while increasing resource costs by $1 \%$.

These coefficients of elasticity reflect the percentage of output growth while increasing resource costs by $\alpha, \beta$ are constant and independent of the factor $K, L$.

In practice, the use of production functions, verification the sum of the coefficients $\alpha$ and $\beta$ on one equality is very important, since it determines the type of economic growth [2]:

1) $\alpha+\beta>1$ (production function with increasing return on a scale) corresponds to intensive economic growth, and in the case of $\alpha>\beta$ there is an intensive economic growth of labor; at $\alpha<\beta$ intensive economic growth of funds;

2) $\alpha+\beta<1$ (production function with decreasing returns to scale) means that output is growing slower than the growth of the factors $K$ and $L$, that is, there is no economic growth (or other important factors remain outside consideration);

3) $\alpha+\beta=1$ there is an extensive type of economic growth (a production function with constant returns on a scale).

Based on research results [8-11] and taking into account the information in the paper [12], one has to agree with the author's opinion [2], that among the important factors not taken into account in the production function of type (1), it is worth noting the elements of scientific and technological progress, in particular, the place and role of information technology. The impact of scientific and technological progress is manifested in the growth or aggregate efficiency of resources, or the effectiveness of an individual resource.

At the same time, the special importance of modern information technologies for economic growth is presented in the work of American economists S. D. Oliner and D. E Sichel [11], who carried out the evaluation of the parameters of the production function, in which the indica- tors of information technology were included as independent factors of production. The authors [11] built a model that assessed the impact on the economic growth of the following three factors:

1) investments in the software;

2) investments in communications;

3) other costs.

Here the labor quality index was included as labor costs. Quality was taken into account by means of indicators of changes in levels of education, qualifications and structure (by level of education and sex) employed - [12].

In the context of the analysis of various important factors of development, one should note the important feature of the apparatus of production functions, the use of which makes it possible to compare the trends of economic development of different countries [6, 13-15].

An analysis of the methodology for constructing a production function using quality criteria, which is the purpose of this article, can be considered as one of the steps for the active use of the production function in practice. At the same time, it will enable to activate promising directions of research of the Ukrainian economy.

The achievement of the above goal led to the following tasks:

1) to introduce the mathematical tools of the methodology of refining the production function using an expanded set of constant coefficients.

2) to propose the main elements of the methodology for building a production function, using quality criteria in practice.

\section{Results and Discussion}

\subsection{The mathematical tools of the methodology for refining the production function using an expanded set of coefficients}

In the paper [6] we propose a method for constructing a function $Y$ with variable elasticity coefficients in the form:

$$
\begin{gathered}
Y(L, K, A, \alpha, \beta)=A \cdot L^{f(L, K, \varepsilon)} \cdot K^{g(L, K, \beta)}, \\
f(L, K, \alpha)=\sum_{i=0}^{M} \sum_{m=0}^{N} a_{i m} \varphi_{i}(L) \varphi_{m}(K), \\
f(L, K, \beta)=\sum_{i=0}^{M} \sum_{m=0}^{N} b_{i m} \varphi_{i}(L) \varphi_{m}(K),
\end{gathered}
$$

where $a_{i m}, b_{i m}-$ constant coefficients; $\varphi_{i}(L), \varphi_{m}(K)-$ transcendental functions.

Ukraine is characterized by an unstable development of the economy. Output data for Ukrainian industry is given in Table 1 . These data are generated by analogy in accordance with the data given in the papers $[5,6]$.

To data Table 1, we will apply the valuation technique and take into account the inflation index (Table 2).

Considering the relative index (Table 2), the obtained 
(calculated) refined data for the parameters $Y, L, K$ and are shown in the Table 3.

Table 1 - Output (general) data on Ukrainian industry [16]

\begin{tabular}{|c|c|c|c|}
\hline Year & $\begin{array}{c}\text { Employed popu- } \\
\text { lation } L \text { in in- } \\
\text { dustry, thousand } \\
\text { people }\end{array}$ & $\begin{array}{c}\text { Volume of sold } \\
\text { industrial prod- } \\
\text { ucts (goods, } \\
\text { services) } Y, \\
\text { million UAH }\end{array}$ & $\begin{array}{c}\text { Investments } \\
K \text { in industry, } \\
\text { million UAH }\end{array}$ \\
\hline 2010 & 3462 & 1043111 & 55384 \\
\hline 2011 & 3353 & 1305308 & 78726 \\
\hline 2012 & 3237 & 1367926 & 91598 \\
\hline 2013 & 3170 & 1322408 & 97574 \\
\hline 2014 & 2898 & 1428839 & 86242 \\
\hline 2015 & 2574 & 1776604 & 87656 \\
\hline 2016 & 2495 & 2158030 & 117754 \\
\hline 2017 & 2441 & 2625863 & 143300 \\
\hline
\end{tabular}

Table 2 - Inflation indicators in Ukraine [16]

\begin{tabular}{|c|c|c|}
\hline Year & $\begin{array}{c}\text { Inflation } \\
\text { index, } \%\end{array}$ & $\begin{array}{c}\text { The value of the inflation index Inf } \\
\text { relative to 2010 year }\end{array}$ \\
\hline 2010 & 109.1 & 1.000 \\
\hline 2011 & 104.6 & 1.046 \\
\hline 2012 & 99.8 & 1.044 \\
\hline 2013 & 100.5 & 1.049 \\
\hline 2014 & 124.9 & 1.310 \\
\hline 2015 & 143.3 & 1.878 \\
\hline 2016 & 112.4 & 2.111 \\
\hline 2017 & 113.7 & 2.400 \\
\hline
\end{tabular}

Table 3 - Data on Ukrainian industry considering the inflation index, million UAH

\begin{tabular}{|c|c|c|}
\hline Year & $\begin{array}{c}\text { Volume of sold industrial products } \\
\text { (goods, services) } Y\end{array}$ & $\begin{array}{c}\text { Investments } \\
K\end{array}$ \\
\hline 2010 & 1043112 & 55384 \\
\hline 2011 & 1248000 & 75263 \\
\hline 2012 & 1310200 & 87738 \\
\hline 2013 & 1260600 & 93016 \\
\hline 2014 & 1090400 & 65813 \\
\hline 2015 & 946000 & 46683 \\
\hline 2016 & 1022500 & 55792 \\
\hline 2017 & 1094100 & 59708 \\
\hline
\end{tabular}

For data Table 3 received a production function of a classical type in the form:

$$
Y_{0}=0.298 L^{0.75} K^{0.25}
$$

For function (7) according to Table 3, square deviation is established $\sigma_{0}=0.108$.

Using the approach of constructing the function of $Y$ with variable coefficients, similar to that in [6], $Y_{1}$ was given a more complex form

$$
Y_{1}=A_{1} L^{\alpha_{1}+\alpha_{2} L+\alpha_{3} K} K^{\beta_{1}+\beta_{2} L+\beta_{3} K},
$$

for which the mean-square deviation $\sigma_{1}=0.093$, that is less comparing with $\sigma_{0}$ by $14 \%\left(\Delta \sigma / \sigma_{i} \sim 0.14\right)$. Here $A_{1}$, $\alpha_{1}, \alpha_{2}, \alpha_{3}, \beta_{1}, \beta_{2}, \beta_{3}-$ are constant coefficients for a given dataset.

To find the refined value $\sigma_{1}$, the classical econometric and mathematical method of exponential smoothing is used to clarify the errors of the results of econometric studies for the Ukrainian industry which do not exceed $\Delta_{1}=8 \%$.

In the paper [6], the deviations of the $\sigma_{i}, \Delta_{i}$ for agricultural products in Ukraine do not exceed $37 \%\left(\Delta \sigma / \sigma_{i} \sim\right.$ $0,37)$.

The ratio (8) shows 7 coefficients $A_{1}, \alpha_{1}, \alpha_{2}, \alpha_{3}, \beta_{1}, \beta_{2}$ and $\beta_{3}$, which can be considered conditionally constant for a given set of data, in particular for industry. If we choose data for a period of 7 years, then we will determine the coefficients of this type with a high accuracy that does not exceed the accuracy of the relevant statistics $\Delta_{1}$. Relevant constraints will be derived from the principles of statistics and metrology for a particular category of research, in particular for the parameters $Y, L, K$, which characterize the Ukrainian industry.

Since the analysis of the effectiveness of using the production function with variable coefficients in the tasks of the study of manufacturing problems, there is a need in the first approximation to test the advanced method of constructing production functions [6].

We draw attention to a plurality of data in the Table 3. Data from Table 3 for $Y_{i}(2010,2014,2016,2017)$ are similar and their errors (deviations from the mean value) do not exceed $\Delta_{2}=3.7 \%$, that is, significantly less error systems of the type $\Delta_{1}\left(\Delta_{2}<\Delta_{1}\right)$. In this case, the task of determining the coefficients $A_{1}, \alpha_{1}, \alpha_{2}, \alpha_{3}, \beta_{1}, \beta_{2}$ and $\beta_{3}$ will be mathematically incorrect and as a result, as established on the basis of a computational experiment, these coefficients will be estimated with a large error of $\Delta_{3} \sim 20-35 \%$.

On the basis of the data analysis Table 3 observe the unstable development of Ukrainian industry. Therefore, there is no point in forecasting trends in the development of industry in Ukraine to apply the ratio (8). Here it is expedient to use the ratio of type (7) for certain small intervals of time, for example, for 2010-2012 and 20122015. For these small periods of time, it is advisable to estimate the rate of change in the coefficients type $A, \alpha$, $\beta$, and information about them to use to predict trends in the volume of sales of industrial products (goods, services) $Y$.

\subsection{Elements of the methodology of constructing a production function using quality criteria}

Like in the works $[17,18]$ we use the product to evaluate the quality of products (industry) $k_{\mathrm{P}}=\left\{k_{1} \cdot k_{2} \cdot k_{3}\right\}$, where $k_{1}$ - coefficient of commercial gain, $k_{2}$ - coefficient of product competitiveness level - [19], $k_{3}-$ coefficient of product reliability.

Similarly to $[17,18]$ and taking into account the information given in the Table 3 and [20-23], the multiplicative qualimetric quality criterion will be presented as: 


$$
Z_{1}=\prod_{i=1}^{6} k_{i} \Rightarrow \max
$$

where $k_{4}$ - coefficient of the level of quality (reliability) of the parameters of the type of production function $Y_{i} ; k_{5}$ - coefficient of quality (reliability) of type parameters $L, \alpha_{1}, \alpha_{2}, \alpha_{3} ; k_{6}$ - coefficient of quality (reliability) of type parameters $K, \beta_{1}, \beta_{2}, \beta_{3}$.

Let's mention the quality criterion of $Z_{2}$ in the additive form in the same way as in scientific work [17]:

$$
Z_{2}=\sum_{i=1}^{6} a_{i} k_{i},
$$

where $a_{j}(j=1,2, \ldots, 6)$ - weight coefficients.

In the first approximation we choose $a_{j}=1 / 6$, a $k_{j}=1 / \Delta_{i}$. In the first approximation, as an example, let it be $k_{1}=k_{2}=k_{3}=1 / \Delta_{1} \approx 12.5$.

According to the Table 3 , it is evaluated: $k_{4}=2.83$, $k_{5}=2.90$, and $k_{6}=5.13$.

As a result, $Z_{1}=214402, Z_{2}=17.11$.

If the errors of the parameters corresponding to the methodology for assessing the quality criteria of the corresponding methodology can be reduced, then the integral parameters of type $Z_{1}$ and $Z_{2}$ will be increased.

\section{Conclusions}

According to the results of the research, a method for evaluating the parameters included in the classical CobbDouglas formula is developed. On the basis of the computational experiment it was established that if the values of the production function $Y$ are close to the numerical values and the deviation between them does not exceed $3.7 \%$, then for approximation of $Y$ in the industry for the period 2010-2017, it makes no sense to complicate its appearance. To predict $Y_{i}$ values, we evaluate the parameters that are included in the classical Cobb-Douglas type formula. To improve the methodology for estimating the coefficients included in the Cobb-Douglas type formula, new variants of the multiplicative and additive quality criteria and for the Ukrainian industry are proposed, based on the analytical data for 2010-2017, the evaluation of the relevant criteria was carried out. The above example has an analytical orientation and illustrates the possibility of using a Cobb-Douglas formula for analyzing the coefficients of a given model with sufficient reliability. Research focused on controlling the development of industry in Ukraine by means of quality criteria.

\section{References}

1. Zahorodnii, A. H., \& Vozniuk, H. L. (2005). Financial and Economic Dictionary. Lviv: Lvivska Politekhnika [in Ukrainian].

2. Shumska, S. S. (2007). Production Function in Economic Analysis: Theory and Practice of Use. Ekonomika Prohnozuvannia, Vol. 2, pp. 138-153 [in Ukrainian].

3. Heiets, V. M., \& Ostashko, T.O. (2016). Implementation of the Association Agreement between Ukraine and the EU: Economic Challenges and New Opportunities. Kyiv, National Academy of Sciences of Ukraine [in Ukrainian].

4. Fandel, G. (1991). Limitational Production Functions. Theory of Production and Cost, pp. 111-146, doi: 10.1007/978-3-642$76812-5 \_4$.

5. Cobb, C. W., \& Douglas, P. H. (1928). A Theory of Production. The American Economic Review, Vol. 18, No. 1, pp. $139-165$.

6. Lytvyn, O. M., \& Artiukh, M. V. (2018). Testing the method of constructing production functions with variable coefficients (PFVCE). Mathematical and computer modelling, Series: Technical Sciences, Vol. 17, pp. 117-123 [in Ukrainian].

7. Lytvyn, O. M., \& Artiukh, M. V. (2012). The Production Function with Variable Elasticity Coefficients, Based on the Experimental Data of Cobb-Douglas. Bulletin of the National Technical University "KhPI", Series: Mathematical Modeling in Engineering and Technologies, Vol. 27, pp. 124-129.

8. Hicks, J. R. (1937). Mr. Keynes and the "Classics"; A Suggested Interpretation. Econometrica, Vol. 5(2), pp. 147, doi: $10.2307 / 1907242$.

9. Solow, R. M. (1956). A Contribution to the Theory of Economic Growth. The Quarterly Journal of Economics, Vol. 70(1), pp. 6, doi: 10.2307/1884513.

10. Harrod, R. F. (1939). An Essay in Dynamic Theory. The Economic Journal, Vol. 49(193), pp. 14, doi: 10.2307/2225181.

11. Oliner, S. D., \& Sichel, D. E. (2000). The Resurgence of growth in the Late 1990s: Is Information technology the Story? The Jornal of Economic Perspectives, Vol. 14(4), pp. 3-22, doi: 10.1257/jep.14.4.3.

12. Skrynkovskyy, R. M. (2018). Diagnosing the Maturity Level of IT Processes at the Enterprise. Business Inform, Vol. 4(483), pp. 377-383.

13. Lukashin, Yu., \& Rahlina, L. (2004). Production Functions in the Analysis of the World Economy. Mirovaya Ekonomika $i$ Mejdunarodnyie Otnosheniya, Vol. 1, pp. 17-27 [in Russian].

14. Mankiw, N. G., Romer, D., \& Weil, D. (1990). A Contribution to the Empirics of Economic Growth. Cambridge, NBER Working Papers Series, doi: 10.3386/w3541.

15. Hall, R., \& Jones, C. (1999). Why Do Some Countries Produce So Much More Output per Worker than Others? Cambridge, NBER Working Papers Series, doi: 10.3386/w6564.

16. State Statistics Servise of Ukraine (2018). Statistical Information. Retrieved from: http://www.ukrstat.gov.ua. 
17. Yuzevych, L., Skrynkovskyy, R., \& Koman, B. (2017). Development of information support of quality management of underground pipelines. EUREKA: Physics and Engineering, Vol. 4, pp. 49-60, doi: 10.21303/2461-4262.2017.00392.

18. Panchenko, S., Lavrukhin, O., \& Shapatina, O. (2017). Creating a qualimetric criterion for the generalized level of vehicle. Eastern-European Journal of Enterprise Technologies, Vol. 1(3 (85)), pp. 39-45, doi: 10.15587/1729-4061.2017.92203.

19. Skrynkovskyy, R. M. (2015). Diagnostics of the Enterprise Production Competitiveness. The Problems of Economy, Vol. 4, pp. 240-246 [in Ukrainian].

20. Amosha, O. I., Bulieiev, I. P., Zemliankin, A. I., et al. (2017). Industry of Ukraine - 2016: The State and Prospects of Development. National Academy of Sciences of Ukraine, Kyiv [in Ukrainian].

21. Parkhomenko, M. N. (2010). International Experience of Providing of Quality of Products. Forum Prava, Vol. 3, pp. 344-350 [in Ukrainian].

22. Pawlowski, G. (2017). Development of the system of management diagnostics of the enterprise: Doctoral dissertation. Retrieved from: http://irbis-nbuv.gov.ua/ASUA/1257760.

23. Yuzevych, V., Klyuvak, O., \& Skrynkovskyy, R. (2016). Diagnostics of the system of interaction between the government and business in terms of public e-procurement. Economic Annals-XXI, Vol. 160(7-8), pp. 39-44, doi: 10.21003/ea.v160-08.

\title{
Аналіз методології побудови виробничої функції з використанням критеріїв якості
}

\author{
Скриньковський Р. М. ${ }^{1}$, Юзевич В. М. ${ }^{2}$, Катаєв А. В. ${ }^{3}$, Павловські ${ }^{4}{ }^{4}$, Процюк Т. Б. ${ }^{5}$ \\ ${ }^{1}$ Львівський університет бізнесу та права, вул. Кульпарківська, 99, м. Львів, 79021, Україна; \\ ${ }^{2}$ Фізико-механічний інститут ім. Г. В. Карпенка НАН України, вул. Наукова, 5, м. Львів, 79060, Україна; \\ ${ }^{3}$ Харківський торговельно-економічний інститут Київського національного торговельно-економічного університету, \\ пров. Отакара Яроша, 8, м. Харків, 61045, Україна; \\ ${ }^{4}$ Компанія “Zaklad Handlowo-Uslugowy ВНР”, вул. Костшинська, 17, м. Гужиця, 69-113, Польща; \\ ${ }_{5}^{5}$ Академія фінансового моніторингу, вул. Білоруська, 24, м. Київ, 04050, Україна
}

Анотація. У статті на прикладі України розроблено методику оцінювання параметрів класичної формули типу Кобба-Дугласа для прогнозування тенденцій розвитку промисловості держави. На основі обчислювального експерименту встановлено, що для значень виробничої функції $Y$, близьких за числовими значеннями і відхиленнями до $3,7 \%$, апроксимування $Y$ у сфері промисловості для невеликих часових періодів $\epsilon$ неможливим 3 огляду на ускладнення множини ії параметрів та коефіцієнтів. Для прогнозування значень $Y_{i}\left(Y_{i} \in Y\right)$ проведено оцінювання параметрів, що входять до класичної формули типу Кобба-Дугласа. Для удосконалення методики оцінювання коефіцієнтів, що входять до цієї формули, запропоновано нові варіанти мультиплікативного та адитивного критеріїв якості. Виходячи із аналітичних даних за 2010-2017 pр., проведено оцінювання відповідних критеріїв для промисловості України.

Ключові слова: виробнича функція, функція Кобба-Дугласа, критерії якості, промисловість, промислова продукція. 